\title{
EVALUASI JARINGAN IRIGASI \\ DESA NYALIAN BANJARANGKAN KLUNGKUNG
}

\author{
Made Novia Indriani ${ }^{1}$, I Nyoman Suta Widnyana ${ }^{2}$
}

\begin{abstract}
ABSTRAK
Salah satu kegiatan pengembangan dan pengelolaan sumber air irigasi yaitu berhubungan dengan pembagian air keseluruh jaringan irigasi. Mengingat kendala pengairan yang terjadi di Desa Nyalian, dimana debit air tidak mencukupi sampai dihilir, sehingga hal tersebut berdampak pada keberlangsungan areal persawahan dan perkebunan warga yang berada di daerah hilir. Sebagai langkah awal untuk mengetahui penyebab, mengevalusainya dan kemudian mencari solusi penanganannya, maka diperlukan kembali pendataan atau inventarisasi elevasi jaringan irigasi serta kondisi saluran irigasi yang terdapat di lingkup wilayah Desa Nyalian Banjarangkan Klungkung.

Kegiatan pengabdian masyarakat ini bertujuan untuk memberikan gambaran keadaan permasalahan yang terjadi untuk kemudian dilakukan evaluasi serta alternative pemecahan masalah. Tahap awal yaitu dengan mendata melalui proses pemetaan elevasi jaringan irigasi serta inventarisasi kondisi bangunan-bangunan saluran irigasi yang ada di sepanjang aliran Dam Cai di Desa Nyalian. Selanjutnya mengevaluasi kondisi saluran existing tersebut terhadap kebutuhan yang diperlukan.

Metode yang digunakan dalam penelitian ini adalah metode survey lapangan melalui observasi, wawancara, pengukuran dan dokumentasi. Untuk pemetaan selain dari pengukuran dilapangan secara manual, proses pemetaan dilakukan juga dengan menggunakan bantuan GPS, untuk mendapatkan elevasi ketinggian aliran pada beberapa desa adat yang ada dalam lingkup Desa Nyalian

Berdasarkan hasil pemetaan, elevasi dari hulu hingga hilir sangat memungkinkan utk mengalirkan air sesuai debit yang diharapkan, mengingat elevasi dari hulu menuju hilir, semakin rendah di daerah hilir. Kendala yang terjadi yaitu pada jenis penampang saluran irigasi yaitu masih berupa saluran alami atau dari tanah. Hal tersebut sangat berdampak pada debit air yang mengalir ke hilir, dimana sesuai dengan sifat yang dimiliki oleh tanah tersebut yang mempunyai sifat permeabilitas, yang artinya, tanah menyerap air yang akan dialirkan sampai di hilir. Alternatif solusi yang bisa ditawarkan yaitu membuat saluran irigasi dari pasangan beton atau pemasangan pipa-pipa di sepanjang saluran irigasi, sehingga air mengalir dari hulu ke hilir sesuai dengan debit yang diperlukan.
\end{abstract}

Kata Kunci : Jaringan irigasi, Pemetaan, Evaluasi

${ }^{1}$ Dosen Teknik Sipil, Fakultas Teknik, Universitas Hindu Indonesia Denpasar
${ }^{2}$ Dosen Teknik Sipil, Fakultas Teknik, Universitas Hindu Indonesia Denpasar 


\section{Pendahuluan}

Pengabdian kepada masyarakat merupakan salah satu bagian dari Tri Dharma Perguruan Tinggi yang merupakan pengalaman IPTEK yang dilakukan oleh Perguruan Tinggi secara melembaga melalui metode ilmiah langsung kepada masyarakat yang membutuhkan, dalam menyukseskan pembangunan dan pengembangan manusia pembangunan. Program Kuliah Kerja Nyata adalah suatu aktifitas perkuliahan dalam bentuk pengabdian pada masyarakat.

Pengabdian kepada masyarakat, diperlukan perencanaan - perencanaan yang disusun dalam program - program yang dirancang sedemikian rupa dengan harapan program - program tersebut dapat terlaksana dengan baik. Sehingga dapat melihat apakah sesuai antara Das Sein ( harapan ) Das Sollen ( kenyataan di lapangan ).

Dalam kegiatan pengabdian kepada masyarakat yang dilaksanakan adalah membuat Pemetaan Saluran Irigasi, di Desa Nyalian. Kegiatan ini dilaksanakan untuk mengetahui gambaran dari saluran irigasi yang sudah ada di Desa tersebut serta mengevaluasi untuk perbaikan kedepannya .

Irigasi adalah suatu sistem untuk mengairi suatu lahan dengan cara membendung sumber air. Atau dalam pengertian lain irigasi adalah usaha penyediaan, pengaturan, dan pembuangan air irigasi untuk menunjang pertanian yang jenisnya meliputi irigasi permukaan, irigasi rawa, irigasi air bawah tanah, irigasi pompa, dan irigasi tambak. Irigasi merupakan upaya yang dilakukan manusia untuk mengairi lahan pertanian. Dalam dunia modern, saat ini sudah banyak model irigasi yang dapat dilakukan manusia. Pada zaman dahulu, jika persediaan air melimpah karena tempat yang dekat dengan sungai atau sumber mata air, maka irigasi dilakukan dengan mengalirkan air tersebut ke lahan pertanian.

\section{A. Analisis Situasi}

Subak merupakan sistem pengelolaan pendistribusian aliran irigasi pertanian khas masyarakat Bali dan terbukti mampu meningkatkan produktivitas pertanian masyarakat Bali. Melalui sistem subak ini para petani mendapatkan jatah air 
sesuai ketentuan yang diputuskan dalam musyawarah warga. Budaya subak dari bali sebagai bagian dari warisan dunia dimana subak dianggap sebagai sistem irigasi yang dapat mempertahankan budaya asli masyarakat Bali. Secara filosofis keberadaan subak di Bali merupakan implementasi dari konsep Tri Hita Karana yang merupakan konsep mengenai hubungan yang harmonis antara manusia dengan Tuhan, manusia dengan alam dan antar manusia. Sebagai lembaga tradisonal di Bali yang mengatur sistem pengairan di sawah beserta pengelolaan jaringan irigasinya, subak mesti dijaga dan dilestarikan.

Selanjutnya (Arif, 1999; Pusposutardjo, 1997) yang meninjau subak sebagai sistem teknologi dari suatu sosio-kultural masyarakat, menyimpulkan bahwa sistem irigasi (termasuk subak) merupakan suatu proses transformasi sistem kultural masyarakat yang pada dasarnya memiliki tiga subsistem yakni: (i) subsistem budaya (pola pikir, norma dan nilai), (ii) subsistem sosial (termasuk ekonomi), dan (iii) subsistem kebendaan (termasuk teknologi). Semua subsistem itu memiliki hubungan timbal-balik, dan juga memiliki hubungan keseimbangan dengan lingkungannya.

Subsistem budaya yang dicerminkan dengan pola pikir pengelolaan air irigasi yang dilakukan dengan landasan harmoni dan kebersamaan. Air dianggap sangat bernilai dan dihormati, serta dianggap sebagai karunia dan ciptaan Tuhan Yang Maha Esa. Selanjutnya (Kutanegara, 1999) mencatat bahwa subak tak bisa dilepaskan dengan masalah air (irigasi).

\section{B. Sarana Dan Prasarana Fisik Irigasi Subak}

Beberapa pengertian dari istilah-istilah berdasarkan PP Nomor 20 tahun 2006 tentang irigasi dan UU Nomor 7 tahun 2004 tentang sumberdaya air yang kiranya penting untuk dituangkan di sini guna lebih memahami pembahasan mengenai aspek prasarana dan sarana irigasi antara lain adalah sebagai berikut.

(1). Air adalah semua air yang terdapat pada, di atas maupun di bawah permukaan tanah.

(2). Sumber air adalah tempat/wadah air baik yang terdapat pada, di atas, maupun di bawah permukaan tanah. 
(3). Irigasi adalah usaha penyediaan dan pengaturan air untuk menunjang pertanian.

(4). Jaringan irigasi adalah saluran dan bangunan yang merupakan satu kesatuan dan diperlukan untuk pengaturan air irigasi mulai dari penyediaan, pengambilan, dan penggunaannya.

(5). Daerah irigasi (DI) adalah kesatuan wilayah yang mendapat air dari satu jaringan irigasi.

(6). Petak irigasi adalah petak tanah yang memperoleh air irigasi.

(7). Petak tersier adalah kumpulan petak irigasi yang merupakan kesatuan dan mendapatkan air irigasi melalui saluran tersier yang sania.

(8). Penyediaan air irigasi adalah penentuan banyaknya air yang dapat dipergunakan untuk menunjang pertanian.

(9). Pembagian air irigasi adalah penyaluran jatah air dari jaringan utama ke petak tersier.

(10).Penggunaan air irigasi adalah pemanfaatan air di tingkat usahatani / lahan pertanian.

(11).Pembuangan air irigasi atau drainase adalah pengaliran kelebihan air irigasi yang sudah tidak dipergunakan lagi 1 pada suatu DI ( daerah irigasi).

(12).Operasi dan pemeliharaan (OP) jaringan irigasi adalahkegiatan pengaturan air dan jaringan yang meliputi penyediaan, pembagian, pemberian, penggunaan, danpembuangannya, termasuk usaha mempertahankan kondisijaringan irigasi agar berfungsi dengan baik.

|13).Rehabilitasi jaringan irigasi adalah kegiatan perbaikan jaringan irigasi guna mengembalikan fungsi dan pelayanan irigasi seperti semula.

(14).Peningkatan jaringan irigasi adalah kegiatan perbaikan jaringan irigasi guna meningkatkan fungsi dan pelayanan irigasi.

(15).Daerah Aliran Sungai (DAS) adalah kawasan yang dibatasioleh pemisah topografis, yang menampung, menyimpan,dan mengalirkan air ke anak sungai dan sungai utama yangbermuara ke danau atau laut, termasuk di bawah cekunganair tanah. 


\section{Jaringan Irigasi Subak}

Sebagai sebuah sistem irigasi, subak memiliki jaringan irigasi atau fasilitas irigasi seperti bangunan-bangunan yang diperlukan untuk pengaturan air irigasi mulai dari sumber air sampai ke petak-petak sawah petani individual.Fasilitas irigasi tersebut terdiri dari saluran-saluran irigasi beserta bangunan-bangunan irigasi yang merupakan satu kesatuan jaringan irigasi.

\section{Saluran irigasi subak}

Saluran irigasi adalah saluran bangunan, dan bangunan pelengkap yang merupakan satu kesatuan yang diperlukan untuk penyediaan, pembagian, pemberian, penggunaan, dan pembuangan air irigasi. Berbagai macam saluran irigasi subak adalah sebagai berikut :

(1) Saluran irigasi primer

Merupakan bagian dari jaringan irigasi yang terdiri dari bangunan utama, saluran induk/primer, saluran pembuangannya, bangunan bagi, bangunan bagi-sadap dan bangunan pelengkapnya. Saluran irigasi primer merupakan saluran irigasi utama yang membawa air masuk kedalam saluran sekunder. Air yang sudah masuk kedalam irigasi sekunder akan diteruskan ke saluran irigasi tersier. Bangunan saluran irigasi primer umumnya bersifat permanen yang sudah dibangun oleh pemerintah melalui Dinas Pekerjaan Umum atau daerah setempat.

(2) Saluran irigasi sekunder

Merupakan bagian dari jaringan irigasi yang terdiri dari, saluran pembuangannya, saluran bagi, bangunan bagi, bangunan bagi-sadap dan bangunan pelengkapnya. Saluran yang membawa air dari saluran primer ke petak-petak tersier yang dilayani oleh saluran sekunder tersebut. Batas ujung saluran ini adalah pda bangunan sadap terakhir. Fungsi dari saluran irigasi sekunder ini adalah membawa air yang berasal dari saluran irigasi primer dan diteruskan ke saluran irigasi tersier.

(3) Saluran irigasi tersier

Terdiri dari beberapa petak kuarter, masing-masing seluas kurang lebih 8 sampai dengan 15 hektar. Petak tersier sebaiknya berbatasan langsung dengan saluran sekunder atau saluran primer. Sedapat mungkin dihindari petak tersier yang 
terletak tidak secara langsung di sepanjang jaringan saluran irigasi utama, karena akan memerlukan saluran muka tersier yang mebatasi petak-petak tersier lainnya

Keberadaan bangunan irigasi diperlukan untuk menunjang pengambilan dan pengaturan air irigasi. Beberapa jenis bangunan irigasi yang sering dijumpai dalam praktek irigasi antara lain Bangunan utama,Bangunan pembawa,Bangunan bagi,Bangunan sadap,Bangunan pengatur muka air,Bangunan pernbuang dan penguras,Bangunan pelengkap

\section{1) Bangunan Utama}

Bangunan utama dimaksudkan sebagai penyadap dari suatu sumber air untuk dialirkan ke seluruh daerah irigasi yang dilayani. Berdasarkan sumber airnya, bangunan utama dapat diklasifikasikan menjadi beberapa kategori

Bendung,Pengambilan bebas,Pengambilan dari waduk,Stasiun pompa

- Bendung

Bendung adalah adalah bangunan air dengan kelengkapannya yang dibangun melintang sungai atau sudetan yang sengaja dibuat dengan maksud untuk meninggikan elevasi muka air sungai. Apabila muka air di bendung mencapai elevasi tertentu yang dibutuhkan, maka air sungai dapat disadap dan dialirkan secara gravitasi ke tempat-ternpat yang mernerlukannya. Terdapat beberapa jenis bendung, diantaranya adalah (1) bendung tetap (weir), (2) bendung gerak (barrage) dan (3) bendung karet (inflamble weir). Pada bangunan bendung biasanya dilengkapi dengan bangunan pengelak, peredam energi, bangunan pengambilan, bangunan pembilas, kantong lumpur dan tanggul banjir.

- Pengambilan bebas

Pengambilan bebas adalah bangunan yang dibuat ditepi sungai menyadap air sungai untuk dialirkan ke daerah irigasi yang dilayani. Perbedaan dengan bendung adalah pada bangunan pengambilan bebas tidak dilakukan pengaturan tinggi muka air di sungai. Untuk dapat mengalirkan air secara gravitasi, muka air di sungai harus lebih tinggi dari daerah irigasi yang dilayani.

- Pengambilan dari waduk 
Salah satu fungsi waduk adalah menampung air pada saat terjadi kelebihan air dan mengalirkannya pada saat diperlukan. Dilihat dari kegunaannya, waduk dapat bersifat eka guna dan multi guna. Pada umumnya waduk dibangun memiliki banyak kegunaan seperti untuk irigasi, pembangkit listrik, peredam banjir, pariwisata, dan perikanan. Apabila salah satu kegunaan waduk untuk irigasi, maka pada bangunan outlet dilengkapi dengan bangunan sadap untuk irigasi. Alokasi pemberian air sebagai fungsi luas daerah irigasi yang dilayani serta karakteristik waduk.

\section{- Stasiun Pompa}

Bangunan pengambilan air dengan pompa menjadi pilihan apabila upaya-upaya penyadapan air secara gravitasi tidak memungkinkan untuk dilakukan, baik dari segi teknis maupun ekonomis. Salah satu karakteristik pengambilan irigasi dengan pompa adalah investasi awal yang tidak begitu besar namun biaya operasi dan eksploitasi yang sangat besar.

\section{2) Bangunan Pembawa}

Bangunan pembawa mempunyai fungsi mernbawa / mengalirkan air dari surnbemya menuju petak irigasi. Bangunan pembawa meliputi saluran primer, saluran sekunder, saluran tersier dan saluran kwarter. Termasuk dalam bangunan pembawa adalah talang, gorong-gorong, siphon, tedunan dan got miring. Saluran primer biasanya dinamakan sesuai dengan daerah irigasi yang dilayaninya. Sedangkan saluran sekunder sering dinamakan sesuai dengan nama desa yang terletak pada petak sekunder tersebut. Berikut ini penjelasan berbagai saluran yang ada dalam suatu sistem irigasi.

Saluran primer membawa air dari bangunan sadap menuju saluran sekunder dan ke petak-petak tersier yang diairi. Batas ujung saluran primer adalah pada bangunan bagi yang terakhir.

Saluran sekunder membawa air dari bangunan yang menyadap dari saluran primer menuju petak-petak tersier yang dilayani oleh saluran sekunder tersebut. Batas akhir dari saluran sekunder adalah bangunan sadap terakhir 
Saluran tersier membawa air dari bangunan yang menyadap dari saluran sekunder menuju petak-petak kuarter yang dilayani oleh saluran sekunder tersebut. Batas akhir dari saluran sekunder adalah bangunan boks tersier terakhir

Saluran kuarter mernbawa air dari bangunan yang menyadap dari boks tersier menuju petak-petak sawah yang dilayani oleh saluran sekunder tersebut. Batas akhir dari saluran sekunder adalah bangunan boks kuarter terakhir

\section{3) Bangunan Bagi dan Sadap}

Bangunan bagi merupakan bangunan yang terletak pada saluran primer, sekunder dan tersier yang berfungsi untuk membagi air yang dibawa oleh saluran yang bersangkutan. Khusus untuk saluran tersier dan kuarter bangunan bagi ini masingmasing disebut boks tersier dan boks kuarter. Bangunan sadap tersier mengalirkan air dari saluran primer atau sekunder menuju saluran tersier penerima. Dalam rangka penghematan bangunan bagi dan sadap dapat digabung menjadi satu rangkaian bangunan.

Bangunan bagi pada saluran-saluran besar pada umumnya mempunyai 3 bagian utama, yaitu.

Alat pembendung, bermaksud untuk mengatur elevasi muka air sesuai dengan tinggi pelayanan yang direncanakan

Perlengkapan jalan air melintasi tanggul, jalan atau bangunan lain menuju saluran cabang. Konstruksinya dapat berupa saluran terbuka ataupun gorong-gorong. Bangunan ini dilengkapi dengan pintu pengatur agar debit yang masuk saluran dapat diatur.

Bangunan ukur debit, yaitu suatu bangunan yang dimaksudkan untuk mengukur besarnya debit yang mengalir.

\section{4) Bangunan Pengatur dan Pengukur}

Agar pemberian air irigasi sesuai dengan yang direncanakan, perlu dilakukan pengaturan dan pengukuran aliran di bangunan sadap (awal saluran primer), cabang saluran jaringan primer serta bangunan sadap primer dan sekunder. Bangunan pengatur muka air dimaksudkan untuk dapat mengatur muka air sampai batas-batas yang diperlukan untuk dapat memberikan debit yang konstan dan sesuai dengan yang dibutuhkan. Sedangkan bangunan pengukur dimaksudkan 
untuk dapat memberi informasi mengenai besar aliran yang dialirkan. Kadangkala, bangunan pengukur dapat juga berfungsi sebagai bangunan pangatur.

\section{5) Bangunan Drainase}

Bangunan drainase dimaksudkan untuk membuang kelebihan air di petak sawah maupun saluran. Kelebihan air di petak sawah dibuang melalui saluran pembuang, sedangkan kelebihan air disaluran dibuang melalui bangunan pelimpah. Terdapat beberapa jenis saluran pembuang, yaitu saluran pembuang kuarter, saluran pembuang tersier, saluran pembuang sekunder dan saluran pembuang primer. Jaringan pembuang tersier dimaksudkan untuk :

Mengeringkan sawah, membuang kelebihan air hujan, membuang kelebihan air irigasi

Saluran pembuang kuarter menampung air langsung dari sawah di daerah atasnya atau dari saluran pernbuang di daerah bawah. Saluran pembuang tersier menampung air buangan dari saluran pembuang kuarter. Saluran pembuang primer menampung dari saluran pembuang tersier dan membawanya untuk dialirkan kembali ke sungai.

\section{6) Bangunan Pelengkap}

Sebagaimana namanya, bangunan pelengkap berfungsi sebagai pelengkap bangunan-bangunan irigasi yang telah disebutkan sebelumnya. Bangunan pelengkap berfungsi untuk memperlancar para petugas dalam eksploitasi dan pemeliharaan. Bangunan pelengkap dapat juga dimanfaatkan untuk pelayanan umum. Jenis-jenis bangunan pelengkap antara lain jalan inspeksi, tanggul, jembatan penyebrangan, tangga mandi manusia, sarana mandi hewan, serta bangunan lainnya.

\section{E. Pendistribusian Air Irigasi}

Bagaimana sistem atau cara penyaluran air irigasi yang telah merupakan jatah atau hak pemanfaatan dari masing-masing subak dalam suatu DI yang terdiri dari banyak subak (subak gede), ke tiap-tiap tempek dalam suatu subak atau ke setiap anggota dalam suatu tempek ataupun suatu kelompok persawahan? Ini sangat tergantung pada ketersediaan air dari DI atau subak yang bersangkutan.Pada 
dasarnya, sistem pendistribusian air irigasi dapat dibedakan menjadi dua, yaitu (i) sistem pengaliran terus menerus secara serentak atau continous flow, dan (ii) sistem giliran (Sutawan \& 2000)

1. Sistem pengaliran terus menerus (continous flow)

Cara ini ditetapkan oleh subak-subak yang airnya mencukupi bahkan berlimpah.Dalam kondisi seperti ini biasanya air disalurkan ke setiap unit, yaitu apakah subak dalam satu DI ataukah tempek dalam satu subak, atau ke setiap anggota dalam suatu tempek secara terus menerus.Air terus mengalir melalui bangunan-bangunan bagi selama masih ada air yang masuk ke saluran induk. Unit-unit yang tidak membutuhkan air akan menutup tembukunya masing-masing. Air yang tidak terpakai dengan demikian akan tersalur ke saluran pembuang dan biasanya pada akhirnya masuk kembali ke sungai. Apabila diperlukan akan dibuka kembali atau hanya sebagian ambangnya ditutup dan sebagian lagi dibuka sesuai kebutuhan. Sistem pendistribusian secara terus menerus sepanjang tahun seperti ini (continous flow) tidak terlalu banyak memerlukan personel untuk mengoperasikannya, jadi, tampaknya dari segi pengelolaan atau manajemen paling mudah untuk dilakukan.

2. Sistem Giliran

Bagi subak-subak yang kekurangan air apalagi pada musim kemarau yang panjang, tentunya tidak akan menerapkan sistem continous flow, sebab belum sampai ke sawah, air sudah habis dalam perjalanan. Oleh sebab itu, tiap-tiap subak mempunyai caranya masing-masing dalam menyalurkan air yang tersedia kepada tiap-tiap unit pengguna.Dalam kondisi ketersediaan air yang terbatas, tentu saja tidak memungkinkan bagi subak secara keseluruhan untuk secara bersamaan memanfaatkannya sehingga perlu diterapkan sistem giliran.Sistem giliran dapat dibedakan menjadi (i) giliran menurut rotasi pola tanam, dan (ii) giliran menurut mulainya waktu pengolahan tanah pada musim tanam padi.

\section{F. Permasalahan}


Mata pencaharian, Topografis kecamatan banjarangkan, sebagian besar penduduk bermata pencaharian sebagai petani dan pekebun. Kepemilikan masing-masing kepala keluarga yg berprofesi sebagai petani memiliki areal persawahan lebih kecil atau sama dengan 50 are.

Adapun permasalahan yang terjadi pada beberapa subak di Desa Nyalian yaitu kendala pengairan. Dimana pada jaringan irigasi tersebut, saluran pengairannya masih alami berupa tanah, hal tersebut mengakibatkan debit aliran air yang mengalir dari hulu yaitu Dam Cai di desa Bungbungan, tidak optimal sampai ke bagian hilir (Tukad Melangit), salah satunya yaitu jaringan irigasi pada Tempek Gelogor, yang diakibatkan karena daya resap air pada saluran air berupa tanah alami tersebut masih tinggi. Sehingga hal tersebut mengakibatkan kurang tercukupinya areal persawahan di Desa bagian hilir dan dampaknya pada keberlangsungan tanaman padi yang ditanam di areal persawahan di Desa tersebut. Kendala tersebut mengakibatkan banyak petani, beralih tanaman dari menanam padi menjadi petani pandan, dan hingga saat ini, areal persawahan yang ditanami padi, masih tersisa $25 \%$ saja dari keseluruhan areal persawahan. Tanaman pandan itupun, dalam keberlangsungannya memerlukan air yang cukup banyak terutama pada musim kemarau selain pupuk yang juga harus diberikan secara rutin. Kebutuhan air untuk keberlangsungan tanaman pandan tersebut tentunya memerlukan pendistribusian air yang baik dan lancar sehingga mampu mencukupi kebutuhan tanaman pandan tersebut.

\section{Metode Pelaksanaan}

Pemetaan saluran irigasi di Desa Nyalian ini bertujuan untuk mengvaluasi jaringan irigasi, karena belum adanya data terkini untuk jaringan irigasi disana. Jadi dengan di laksanakan program pemetaan saluran irigasi ini dapat berguna nantinya bagi masyarakat Desa Nyalian. Kegiatan awal dalam melakukan program pemetaan ini adalah dengan mengumpulkan referensi mengenai irigasi Kegiatan berikutnya yaitu kegiatan inti. Ada tiga tahapan dalam proses pemetaan saluran irigasi Desa Nyalian ini yaitu meliputi observasi, pemantauan GPS,dan penggambaran 


\section{A. Observasi}

Guna mencari data data di lapangan yang nantinya akan di gunakan sebagai pedoman untuk membuat gambar pemetaan saluran irigasi tersebut. Di lakukan observasi ke lapangan yang di mulai dari hulu sungai yaitu Dam Cai sampai ke hilir sungai Desa Nylian. Dalam kegiatan observasi ini di lakukan pengukuran panjang dan lebar saluran menggunakan meteran, juga di lakuan pengukuran pada bangunan bangunan irigasi yang ada disana

\section{B. Pemantauan GPS}

Setelah observasi ke lapangan, di lakukan pemantauan dengan menggunakan Sofware Google Earth. Tahapan ini di lakukan untuk menentukan titik koordinat jalur irigasi, panjang jalur irigasi dan juga untuk mengetahui perbedaan elevasi dari hulu sungai sampai ke hilir sungai. Pada tahapan ini di dapatkan data berupa JPG yang berisikan jalur irigasi yang ada di sana, yang nantinya akan di gunakan sebagai patokan untuk menggabar pemetaan saluran irigasi

\section{Menggambar}

Setelah mendapatkan data langsung dari lapangan dan juga data digital dari pemantauan GPS maka kegiatan selanjutnya adalah menggambarkan pemetaan jalur irigasi tersebut. Pada tahapan menggambar ini menggunakan Software AutoCAD. Hasil pemantauan GPS yang berupa gambar JPG tadi di import ke dalapam program AutoCAD yang memungkinkan untuk menggrambar bentuk jalur irigasi tersebut dan juga mencocokan ukuran panjang dan lebar saluran irigasi yang sudah di dapatkan dari observasi lapangan.

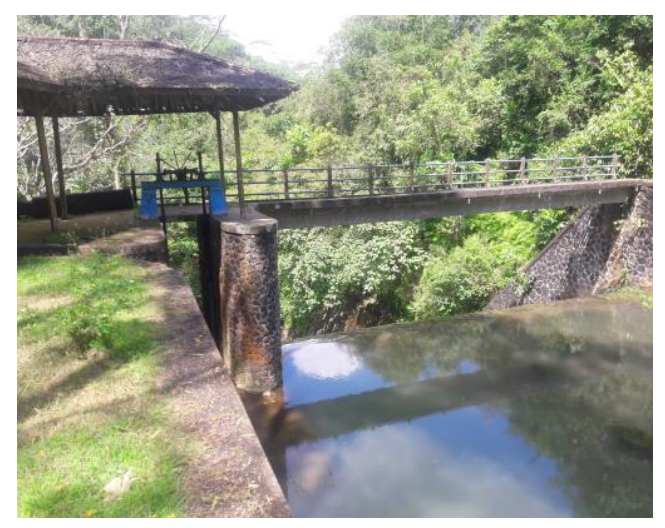

Gambar 2.1 Bendung Dam Cai 




Gambar 2.2 Kondisi fisik Bendung Dam Cai

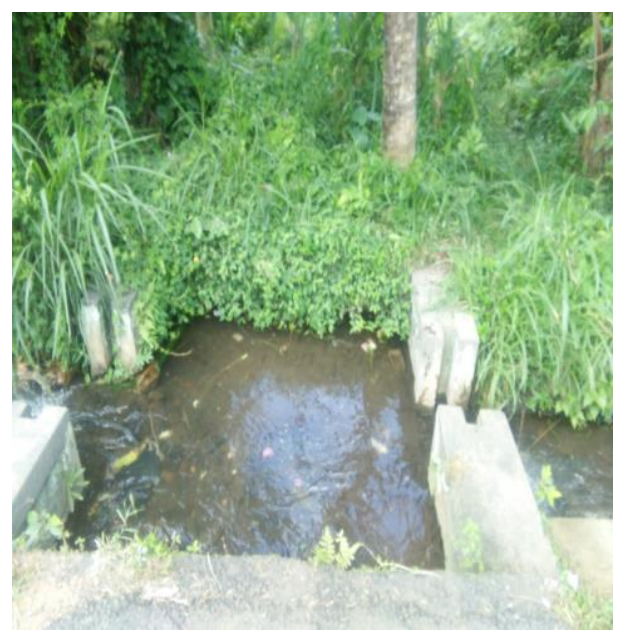

Gambar 2.3 Bangunan bagi di Desa Uma Anyar

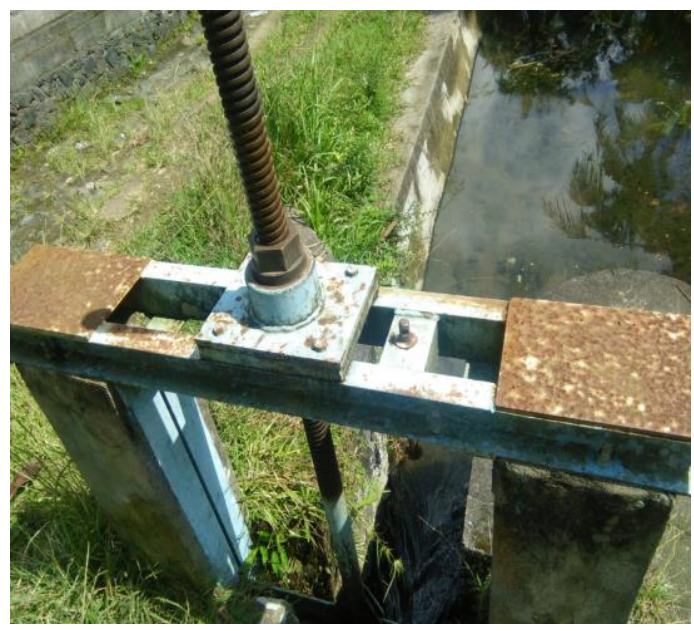

Gambar 2.4 Pintu bangunan pembagi 


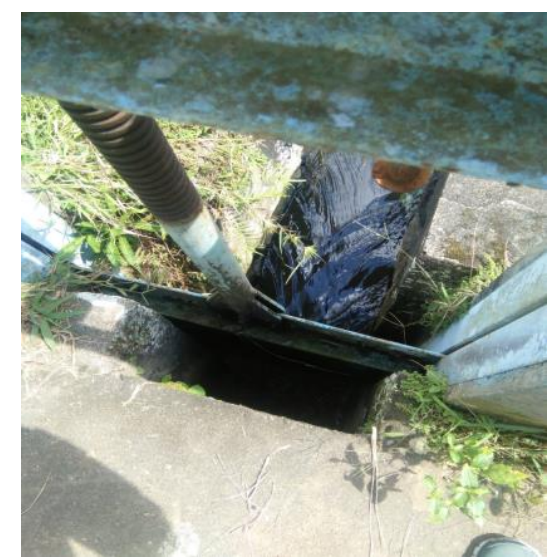

Gambar 2.5 Pintu saluran bagi sadap

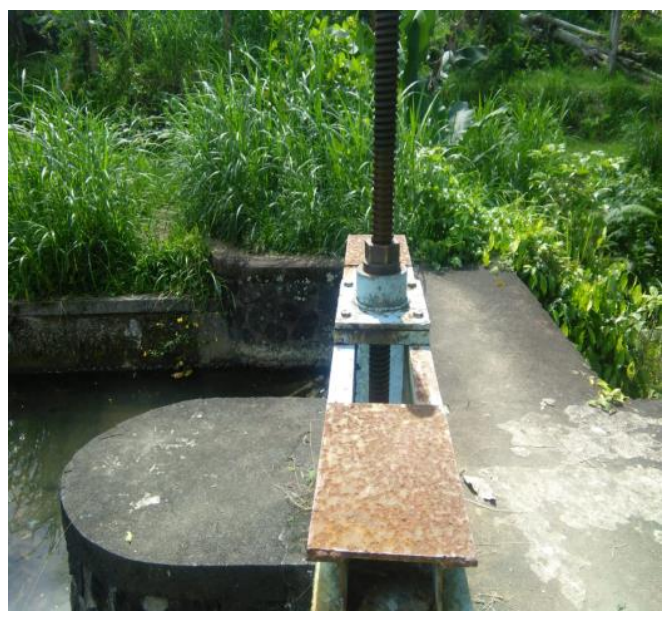

Gambar 2.6 Bangunan bagi sadap



Gambar 2.7 Bangunan bagi sadap 


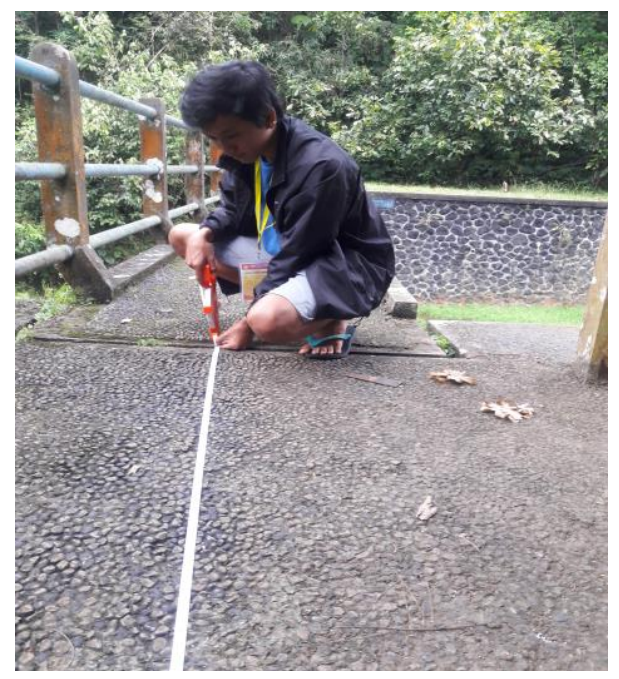

Gambar 2.8 Pengukuran

\section{Hasil dan Pembahasan}

Dari gambar yang di hasilkan dan observasi lapangan dapat di evaluasi untuk keseluruhan saluran irigasi di sana sudah berfungsi dengan baik, elevasi dari hulu sungai sampai ke hilir sungai sudah sesuai untuk dapat mengalirkan air dari elevasi tinggi menuju elevasi yang lebih redah.. Untuk bangunan irigasi di sana ada tiga bendung dan tiga bangunan bagi sadap yang masih berfungsi dengan baik.

Untuk Desa Adat Tegal Wangi sendiri masih belum ada bangunan irigasi, pada saluran sekundernyapun masih berupa tanah yang belum di beton, sehinga air yang mengalir pada saluran irgasi di Desa Adat Tegal Wangi yang berada paling hilir masih belum memadai dikarenakan saluranya yang belum di beton sehingga adanya daya resap tanah yang tinggi membuat air yang mengalir menjadi tidak efektif. 


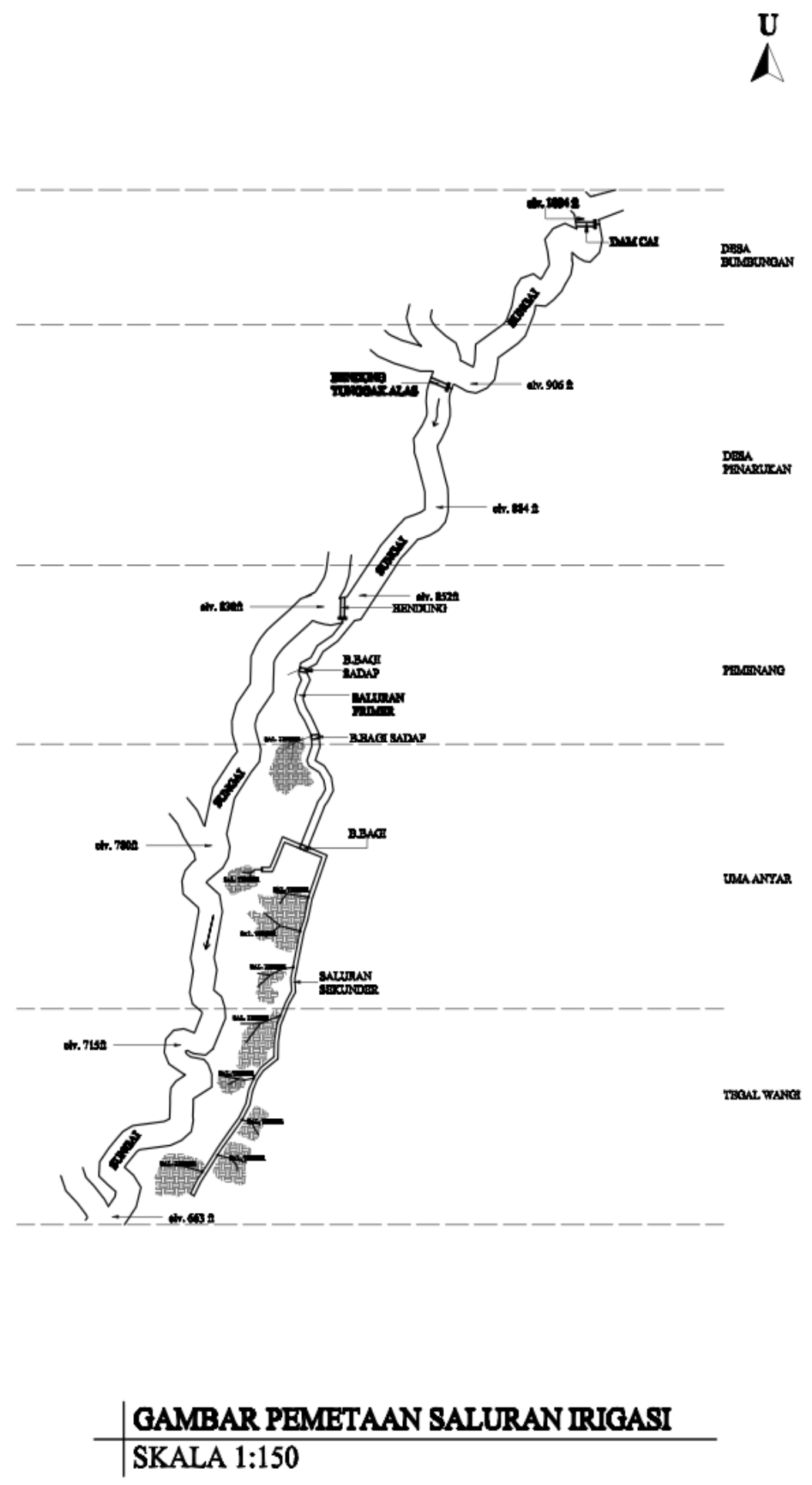




\section{Penutup}

\section{A. Simpulan}

Adapun simpulan dari kegiatan pengabdian masyarakat yaitu

1. Pemetaan yang dilakukan melalui tahapan observasi, wawancara, dokumentasi dan survey, penggunaan GPS serta pengambaran dengan program autocad, didapat elevasi dari hulu yaitu wilayah desa adat Bumbungan dengan Bendung Dam Cai $1034 \mathrm{ft}$ dan daerah hilir yaitu wilayah desa adat Tegal Wangi dengan elevasi $663 \mathrm{ft}$. Setelah desa adat Bumbungan, aliran air menuju Bendung Tunggank Alas yang terdapat di wilayah desa adat Penarukan dengan ketinggian elevasi hingga $884 \mathrm{ft}$, dilanjutkan menuju bangunan bagi sadap dan saluran primer yang terdapat di wilayah desa adat Pemenang dengan elevasi hingga $830 \mathrm{ft}$. Kemudian aliran air irigasi melalui bangunan bagi dan saluran sekunder yang terdapat di wilayah desa asat Uma Anyar dengan elevasi $780 \mathrm{ft}$, dan terakhir di bagian hilir yaitu di wilayah desa adat Tegal Wangi yang hanya berupa saluran-saluran tertier dengan elevasi terendah $663 \mathrm{ft}$. Secara keseluruhan, pendistribusian air irigasi jika dilihat dari elevasi sudah memadai, selain itu kondisi bangunan-bangunan irigasi juga masih cukup memadai dan dapat berfungsi dengan baik. Untuk beberapa saluran sekunder dan tertier masih berupa saluran alami tanah, dan hal tersebut menjadi pemicu berkurangnya debit air yang sampai ke wilayah dengan elevasi yang lebih rendah, mengingat tanah memiliki sifat berpori, sehingga air yang akan meresap dalam tanah sebagai material penampang saliran irigasi tersebut.

2. Dari hasil evaluasi pemetaan tersebut dan kondisi penampang saluran irigasi tersebut, maka alternative solusi yang dapat direncanakan yaitu dengan membuat saluran irigasi beton atau pemasangan pipa-pipa talang di sepanjang saluran irigasi.

\section{B. Saran}

Untuk jenis penampang saluran sebaiknya diganti dengan penampang saluran beton atau pemasangan pipa-pipa disepanjang saluran irigasi, yang tentunya 
kegiatan tersebut memerlukan dana yang tidak sedikit, sehingga hal tersebut memerlukan bantuan dari Pemerintah serta pihak-pihak yang terkait, demi keberlangsungan produktivitas tanaman serta subak itu sendiri.

\section{Daftar Pustaka}

Arif, S. S. (1999). Applying Philosophy of Trihita Karana in Design and Management

of Subak Irrigation System (Vol. Vol.III). Yogyakarta: Fac.of

Agric.Technology, Gadjah Mada University.

Kutanegara, P. M. d. H. A.-P. (1999). Concept of Balinese life of tri hita

karana as cultural base of subak institution (Vol. Vol.III. ). Yogyakarta: Fac. of Agric.Technology, Gadjah Mada University.

Pusposutardjo, S. (1997). Nilai Ekonomi Sumber daya Air. Paper presented at the Forum diskusi kelembagaan sektor pengairan, Surakarta.

Sutawan, \& (2000). Mengembangkan Organisasi Ekonomi Petani

Berbasis Subak : Corporate Farming, Ataukah Ada Alternatif Lain? VISI Irigasi, Sumberdaya Air, Lahan, dan Pembangunan, Nomor 19. 